\title{
INFORMATION SECURITY IN THE SYSTEM OF ENSURING NATIONAL SECURITY
}

\begin{abstract}
As a system-building factor for a modern and dynamically developing society, the information sphere significantly influences the political, economic, cultural, protective, and ideological general state and elements of the states', nations' and individuals' life security, which highlights the importance of information security in the national security system.

Information security is a state of national community where the comprehensive and safe protection of a person, society and state is guaranteed from all sorts of information risks and threats, radically oriented political and social forces. Consequently, information security is a complex process to gradually overcome any information risk. The challenges and threats the information security faces determine the specific content of the practical steps and measures that ensure the national security.
\end{abstract}

Keywords: security, information security, national security, information, information resources, information systems, information society.

The issue of ensuring community security is vitally important to the realization of the national interests and the development of a national policy aimed at the preservation and reproduction of the social system. Since the ancient times to our days, the issue of ensuring security of the socio-cultural life has been considered as a supreme goal of practical and theoretical significance. Though the concept of security has historically been transformed, developed, the original understanding of the phenomenon remains the same: self-preservation and absence of risk.

The informatization procedure results in a new element of national security - information security. In recent years, the secure advancement of the information sphere has earned ex- ceptional importance in the complex and controversial processes of globalization.

Currently, many of the most important interests of a person, society and state are substantially determined by the quantitative and qualitative characteristics of the information sphere surrounding them. It can be justified said, that information security is the most important element of national security that penetrated into all other types of security. The priority of this or that type of security is determined by;

- the need for the functioning and development of the citizens,

- a wide range of dangers and threats for the society, the state and the international community that can be resisted and coun- 
teracted with a specific security and resistance system.

Clearly all these factors are also applicable to information security. Information security is the state of protection of the national interests of the Republic of Armenia in information sphere, which is determined by the balance interests of the society and the state.

The information sphere includes protecting human and citizens constitutional rights and freedoms while receiving and using information, ensuring Armenia's spiritual and political development, preserving and strengthening the country's moral values, its patriotic and humanitarian traditions, cultural and scientific potential. The absence of the Armenian society's fundamental vital values, that of the risks of its interests is perceived as a national security and furthermore, as the state's information policy objective and the highest value. Secondly, it includes information support of the RA state policy. It provides reliable information to the Armenian and international community, the official position of the state about the most important political and social events in the republic and in the international life, ensuring the availability of citizens to the public open media.

The third component of national interests in the field of information is the development of modern technologies, including informational means, telecommunication and communication industry. It includes also the ensuring of needs of national market of information products and the output of that product to the international market, as well as the preservation and effective use of national information resources.

The fourth component is the protection of information resources from unauthorized access and ensuring the security of information, communication and telecommunication systems. From this point of view, the issues of providing information security in Armenia include:

- active counteraction of the adversary's advocacy and psychological activities, constant improvement of its forms and means,

- training of information security specialists in the field of defence.

To clarify the conceptual understanding of information security we need to start analysing the entities of the information relations, their interests and needs. In other words, the concept of "information security" is closely linked to the socio-philosophical categories of "national interests" and "goals". The landscape of the national interests of information and communication technologies use is the sum of the information, accessibility, integrity and confidentiality of the supporting infrastructure.

In terms of information security ensuring, the goal is the active protection of the interests and requirements of the information relations subjects. Though the interests are miscellaneous, all of them are concentrated on ensuring information availability, completeness and confidentiality.

National interests are considered in 3 aspects within the framework of information sphere. These aspects represent different levels of how the interests are manifested:

1. Level of individual interests in the sphere of information, where we analyse human and citizen's constitutional rights. These rights ensure the information availability, the use of information for the sake of an individual's physical, spiritual and intellectual development, as well as the effective protection of information that provides 
one's personal security. One's personal information security is determined by the level of how his/her psychological state and consciousness are protected from possible risky impacts. It's noteworthy, the information impact itself is not as dangerous/useful as its powerful materialenergetic effect (Melyukhin, 1999, p. 84.)

2. Level of social interests. Here we deal with democracy strengthening, legal and social state building, dialogue and public consent establishment.

3. Level of state. State national interests require creating favourable conditions for the harmonious development of the Armenian information infrastructure, the provision of state and public security, the full realization of human and citizen's constitutional rights and freedoms. The sovereignty of legislative procedures and the inviolability of territorial integrity in Armenia are in an inseparable dialectical relationship. The faster and more successful are human and citizen's rights and freedoms performed, the more effective is the process of the RA information security strengthening. This progress largely depends on the level of development of a person's, society's and state's information requirements - the higher is the level of the information requirements, the stronger is the orientation towards a person's spiritual and intellectual development. Additionally, a person's vital activities are built more closely to the targeted requirements of the RA information security concept. Based on the RA national interests records in the sphere of information, the strategic and current issues of the foreign and domestic policy aimed at ensuring information security are formulated.

A society and state's information security is characterized by the practical potential to resist, suspend and neutralize the informational influences that deconstruct, destabilize, endanger and violate the country's interests, as well as by the high level of information protection and therefore, by the relative stability of all the fields of the society's vital activity (economy, science, technosphere, governance, military affairs, social consciousness, etc.). It is a systembuilding and a system-friendly feature. Transforming and developing social systems are stabilized by the fact that they are practically capable of perceiving and absorbing their transforming external and internal stimuli, organically incorporating into the democratic process, conflict prevention and their use. From this point of view, there may be dangerous informational effects and, therefore, information security objects - the minds of people, the mental world, the information-technical systems of different scales and significance and information security social objects - the individual, society, the state, and the international community.

Information security objects can be considered the structures that are occupied with security. They can be both executive and legislative bodies. The role of state bodies in ensuring security is indispensable. In order to ensure information security in the country, state bodies should evaluate the state of the information sphere, develop and adopt new norms and programs of information security, periodically inform the public about the situation of information security and about the work of state bodies in this field, protect citizens, society and state interests and rights. We must take part in the overall process of devel- 
oping international law norms in this area, define new criteria and principles. State bodies should disclose the internal and external threats of the information sphere; determine the direction of these threats.

While accounting the interests of information relations subjects, security provision implies creating favorable conditions that enable the realization of the interests of information relations subjects. Moreover, vital interests and values of participants are highlighted here.

In the context of information relations, values are manifested by the means of the needs, interests and objectives of security ensuring (Partyka \& Polov, 2002). Moreover, it is impossible to understand what is going on in the field of information relations, where they are moving to, what the main problems are that the system of information security faces, if we do not understand the tendencies of the changes in the information values the members of the transitional post-Soviet society accept, if we do not perceive how those changes are linked to the informatization of economy and political structures, in other words, to the newest information and intellectual technologies. It is worth mentioning that the security of the social subject is associated with complicated and controversial processes for mastering the necessary conditions of own existence. This means that security implies the creation of conditions in which the subjects can be able to preserve and reproduce the fundamental values of their national existence.

As a contemporary Russian researcher G. V. Ivashchenko rightly says, the provision of information as a unique process of possessing the existence conditions is at the same time a complicated and controversial process of the subjects' freedom as a materialization of the ability to control its own existence conditions (see Ivashchenko, 2000, pp. 56-58).

Freedom and information are the fundamental characteristics of the social and national subjects. The objective to implement the fundamental vital interests of socio-national subject of information leads to the issue of the actual protection of human and citizen's constitutional rights and freedoms, as well as to the effective protection of information in the sphere of access to information. Thus, the security of information is a state of the society in which a reliable and comprehensive defense of the individual, society and state is ensured by all kinds of informational threats and radical political and social forces. Therefore, information security is a complex process of denial and overcoming any information danger. The content of practical security activities are determined by information security challenges and dangers.

At the same time, it is important to pay attention to the fact that information security assumes not only effective protection against information threats and challenges but also the normal development of information reality when that reality will be protected from new risks of reproduction of information threats. The necessary condition for providing information security is the transition to a new strategy for sustainable development of the society. The development of transitional societies cannot be effective without the new concept of information security and strategy.

It is quite evident that a productive national policy in this field will largely depend on clarifying the priorities of the scientific research on this issue, developing equivalent national models for information security and new approaches to their solution. We think that the 
development level of the philosophical methodological issues currently under consideration remains low.

As Professor E. A. Harutyunyan notices, "the socio-cultural and ethno-cultural perspectives (which possess an important role in ensuring security and reliability of social systems) of the security issue have not yet been deeply analyzed socio-philosophically (Harutyunyan, 2002, p. 53).

Analyzing the concept of information security and its research areas, we may draw the following inferences:

1. The Information Sector, as a coordinating factor of social and national life, requires the identification of the information and psychological security needs of the individual, society and state, rebuilding the existing juridical framework, which ensures the proper protection of the interests of the individual, society and state in the field of information. The national security of Armenia is essentially depended on the complexity of the country's information security and because of technical progress the dependence will gradually increase.

2. Though most of the researchers pay attention to the information security issues in the Republic of Armenia, there is no tangible progress in the field of their sociophilosophical comprehension. As mentioned above, a number of methodological aspects of the issue are under-developed, which makes it difficult to create an efficient information security system of the RA. Still, there are few monographs in the domestic science devoted to the interdisciplinary study of social-philosophical, political and sociological aspects of information security in Armenia.
3. The term "information security" has a broader meaning in the official "RA information security" concept. In our opinion, it is resulted by the unilateral combination of the "national security" and "information security" concepts. The information security system still being formed in modern Armenia is unable to productively and consistently resist the new threats yet. Thus, for instance, the significant imperfection of the governance structure, the loss of a person's secret or that of the correspondence confidentiality, as well as providing the society with overdue, distorted or biased information may be considered as threats to the state. We need to develop and adopt national laws on "Information Security Basics" and "InformationPsychological Security Basics”. Armenia's progress to the information society implies an effective protection of national interests in the information sphere, consistent and practical realization of the main provisions of the RA information security concept. Additionally, we need to find solutions to the urgent issues of ensuring information security for the relevant objects. First of all, this refers to the national information resources, information and communication structure, telecommunication and communication systems and facilities necessary for the stable development of the society and state. We need to improve the level of effectiveness of coordinating the state organizations and departments activities in the field of information security.

From our viewpoint, the socio-philosophical understanding of "information security" concept is relevant and accurate. We believe it characterizes the collective 
integrity of information; its production; processing and preservation facilities; information infrastructure; entities dealing with collection, design, dissemination and use of information; as well as the system that regulates the social relations in the field. To describe information security we should consider it as a unique part of modern society, a section, a special viewpoint, as its immediate being.

4. The analysis of information security issues should include the revelation of the interests of information relations subjects, which are connected to the use of information systems. The risk to information security is only the opposite site of the use of information technologies.

5. The mapping of the interests of subjects linked to the use of information technologies may be divided into components of ensuring information and supporting infrastructure availability, integrity and confidentiality. The key point in various activities in the field of information security is to effectively and comprehensively protect the social, national and state interests of information relations entities.

6. Information security studies are carried out at both intrastate, national-state, interstate /regional/ and local authorities' levels. Additionally, in the fields of functioning of political authorities' state bodies, civil society, as well as person's information security area.

7. The effective state policy in the information security sphere largely depends on the correct selection of research priorities of national issues, the level of the interdisciplinary and philosophical approaches to their settlement.
Given the current conditions exceptional for the dissemination of the Internet, network and computer technologies, the modern society's information resources are being exposed to a significant number of risks full of various damages and losses, creating new threats and challenges for the national information infrastructure (see Ghalechyan, 2016, pp. 7-11).

\section{REFERENCES}

Ivashchenko, G. V. (2000). Doctrine of Information Security and Methodological Problems of the Theory of Security (Doktrina informatsionnoi bezopasnosti i metodicheskie problemy teorii bezopasnosti, in Russian). Materials of the round table "Global Informatization and Social- Humanitarian Problems of Human, Culture, Society", (pp. 48-63). Moscow: MSU.

Ghalechyan, A. (2016). Information Struggle in the military field (Teghekatvakan payqary' r'azmakan olortum, in Armenian). Yerevan: Noravank SEF.

Harutyunyan, E. A. (2002). The Problem of Combination of Civilization and $\mathrm{Hu}$ man Qualities (Qaghaqakrt'ut'yan u mardkayin orakneri hamateghman himnaharcy', in Armenian) Transitional Society/Socio-Cultural Transformations, 52-68.

Partyka, T. L., \& Polov, I. I. (2002). Information Security (Informatsionnaya bezopasnost', in Russian). Moscow: Infra $-\mathrm{M}$.

Melyukhin, I. S. (1999). Informatsionnoe obshchestvo (Informational Socienty, in Russian). Moscow: MSU. 